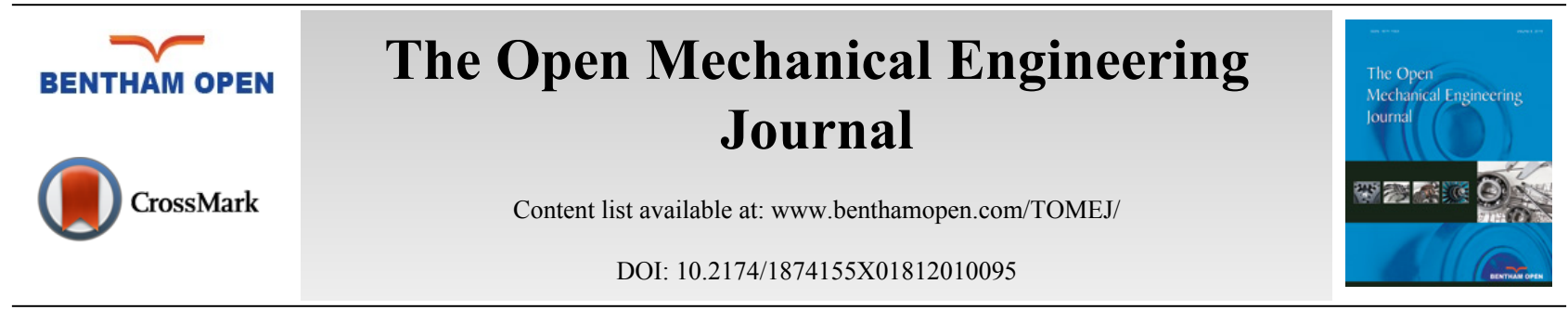

RESEARCH ARTICLE

\title{
Performance Evaluation of Mechanical Power Amplifier for Various Belt Materials
}

\author{
S. H. Gawande* \\ Department of Mechanical Engineering, M. E. S. College of Engineering Pune, S. P. Pune University, Maharashtra, \\ India
}

Received: March 02, 2018

Revised: March 20, 2018

Accepted: April 24, 2018

Abstract:

Background:

In many applications, it is required to control a large output load using a relatively low control force. To satisfy such purposes, a device like mechanical power amplifier can be used which generally gives a very fast response. As per the requirement of the system, power can be instantaneously available from continuously rotating drums of the mechanical power amplifier.

\section{Objective:}

This paper focuses on the computation of amplification factor of the mechanical power amplifier for different rope materials like leather, woven cotton and steel rope.

\section{Method:}

In this study the experimental analysis is performed. A capstan is a simple mechanical amplifier-rope wound on a motor-driven drum. The drums rotate continuously but communicate torque only when the input shaft is rotated to constricts drum A as shown in Fig. (3).

Results:

From the experimental analysis, it endorses that when the optimal number of turns tend to two, power amplification factor is to be 2.23 for leather contact, 1.867 for woven cotton contact, 1.32 for steel contact of rope.

\section{Conclusion:}

From the experimental analysis, it is seen that power amplification is higher for leather as compared to woven cotton and steel. The results are remarkably consistent with experimental measurements including favorable calculation of amplification factor.

Keywords: Mechanical power amplifier, Capstan principle, Rope drive, Drum, Motor, Gear train, Lay shaft.

\section{INTRODUCTION}

The Mechanical power amplifiers are those devices which are based on capstan principle. These devices vary the control force and amplify the power share partially supplied to the drum. Two rotating drums mounted back to back can supply the bi-directional power between input and output shafts. It replaces conventional transducers which are used in the electrical, hydraulic, pneumatic systems. Thus, it reduces the possibility of the cumulative error due to the use of transducers. The capstan principle is also known as belt friction equation as well as Eytelwein's equation. It relates the hold-force to the load-force when flexible rope line is wound around a cylinder, in this case because of the interaction

* Address correspondence to this author at the Department of Mechanical Engineering, M. E. S. College of Engineering Pune, S. P. Pune University, Maharashtra, India; Tel: +912026163831; E-mail: shgawande@gmail.com 
of frictional forces between rope \& drum, tension in the rope, the resultant force acting on the rope line wrapped around a capstan drum may be different on its either side.

This paper focuses on the study related to design and tests of the proposed prototype of power amplifier to evaluate its performance through amplification factor by design optimization for a number of turns of rope, different material (Leather, woven cotton, steel) and proper sizing of its assembly.

\section{LITERATURE REVIEW}

Attaway [1] explains that the frictional force plays an important role in rope rescue operation. Understanding of the various factors that affect rope friction, is essential. This paper highlights the frictional force in the rope which depends upon the load on the rope, the coefficient of friction and the angle that the rope turns through which lead an exponential change in rope tension. Thomas et al. [2] gave insight about the experimental categorization of a continuously variable linear force amplifier based on the theory of capstans in which an elastic cable used to enable a control actuator, not only to continuously clutch output to a rotating drum but also passively declutch by releasing tension. Their design allows more turns and thus results in higher amplification ratios, without the binding of ropes around the drum with the use of elastic cable. It avoids binding due to elastic cable's high bending stiffness and the casing has been used around the drum through which elastic cable follows helical wraps. It also shows elastic cable is preferable over regular cord as it reduces spring back effect. Morten et al. [3] worked on a petroleum well intervention winch system. This system uses a bending flexible rope in the order to provide the reduced size of the drum and all sheaves and wheels over which the rope passes. The system includes for all moving components confined in a high-pressure housing, and has a capstan drive, used for taking the load of the rope running with the tool string in the well. When the access to well is open, the invention allows for a slender and robust vertically extending unit for being mounted on a tool string gate chamber on a wellhead, the winch system for operating under well pressure.

Brandt [4] worked on an automated rail car gate operating system for capstan-operated rail-car gates sequentially locates and opens and closes gate operating capstans on the fly as the car move along across a cargo receiving pits that, in addition to automatically unloading stationary railcars. This results in exclusion of a separate indexing system. Worked performed by Schena and Cooper [5] relates to a compact design of capstan drive which includes a drum, a coupled hub, a passage extending through the drum and hub and a shaft extending through the drum and hub. The shaft engages the passage such that the shaft can transmit a torsional force to the drum and the hub which are free to move along the length of the shaft. This system controls the cable drive which the driver of servo mechanisms that is coupled to the robotically controlled working tool to drive and control the movement of the tool. As space in the surgical field where robotically controlled working tools are being used is to be optimum. It aims to minimize the angle in the cable at the take-off point of the capstan while at the same time providing a compact mechanism to drive and control movement of a robotically controlled working tool. Tjader [6] work relates to pulling equipment for use in trenchless pipe replacement. Trenchless pipe replacement technique is used to replace large-diameter underground pipes used for water, sewage mail lines. This method includes inserting a flexible line through an existing pipe and attaching a bursting tool to a distal end of the flexible line. The method also includes a proximal end of the flexible line to a pulling device. Coupling to the pulling device includes routing the flexible line around the capstan and rotating the capstan to pull the bursting tool through existing pipe. For rotating capstan includes powering a harmonic drive gear reduction coupled to the drum. Jenkins [7] represents a case study on the development of a capstan drive with feedback control for use in optical fibre production. Uniformity of diameter of optical cable is a critical concern for its effective operation and optimum cost control. This can be achieved by the design of an optical fibre draw capstan pulley. Key steps in the design and development of the capstan system include the motor selection, design of capstan pulley and belt material. The system modelling of the process and selection of design parameters using multidisciplinary criteria was used to develop a machine that performed better than had the design been serially completed by each engineering discipline. Bingaman [8] developed an apparatus and method for controlling the speed of a tape drive having an ingoing capstan and an outgoing capstan with a magnetic head in between. These capstans are driven by DC servo motors. Two phase Lock loop servo-circuits are used to initiate the drive motors'. Lewis and Oaks [9] improved the performance of magnetic recording apparatus by the use of the dual capstan type. This dual capstan drive consists of a reversible drive motor which connected to the two capstans by a belt-coupling system. This will cause the lead capstan to be rotated at a slightly higher speed than the other capstan because of which a certain minimum tape tension across the transducer heads of the recording apparatus at all times. Gambhire et al. [10] designed and developed a mechanical power amplifier, which is structurally much simpler as compared to the prior amplifier. Hu et al. [11] developed a displacement amplifier to integrate into an extensometer to improve precision and resolution of the extensometer, 
whereas the outcomes of $\mathrm{Hu}$ et al. [12] show that the belt vibrates at well-separated modal frequencies that increase with the axial speed. Shahosseini et al. [13] report the design optimization, of a mechanical amplifier to generate power from low amplitude and low-frequency vibrations in the manifestation of hefty static displacements, whereas Mushiri et al. [14] designed a power saving conveyor system which involves sizing, selection and cost benefit analysis of its installation result in high starting torque and more operating hours. Pawar et al. [15] studied existing belt conveyor system and optimize the critical parts like roller, channels and support for minimizing the overall weight of assembly in order to obtain an optimized design.

After studying all above research papers, we have reached to the basis of concept that, capstan amplifier generally consists of rope wound around the drum. It is desirable to have a compact design with an elastic rope which should not be rigid otherwise substantial portion of tension will be utilized to overcome the same. As a result, it can amplify the load connected to an output end of rope by virtue of its interaction with the tension in the rope, coefficient of friction between the rope and drum and also number of turns of rope. While some of the parameters like drum diameter, input driving system consist of motor drive shall be optimized to control cost and make the more compact design. However, the likelihood of binding also increases with an additional number of turn of rope. When binding occurs, the increased tension in the cord causes the rope to effectively adhere to the drum, thus changing the kinetic friction coefficient greater than static friction coefficient. Rope binding on the drum result in the loss of control over the tensile loading of the output rope.

\section{THE WORKING PRINCIPLE FOR MECHANICAL POWER AMPLIFIER}

The working principle of mechanical power amplifier is based on capstan norm, which primarily consists of two counter rotating drums and rope wound around it as shown in Fig. (1). The working principle for the mechanical power amplifier is given by below capstan equation:

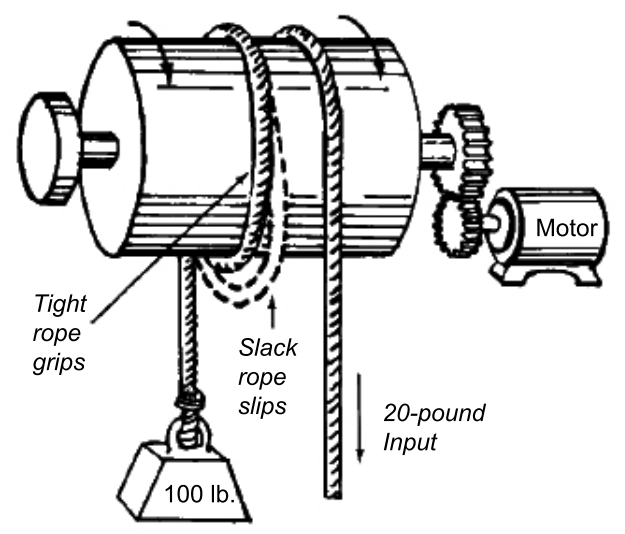

Fig. (1). Basic layout of mechanical power amplifier.

$$
T_{\text {load }}=T_{\text {hold }} e^{\mu \varphi}
$$

where $T_{\text {laod }}$ is the realistic tension on the rope line, $T_{\text {hold }}$ is the subsequent force exerted at the other side of the capstan, $\mu$ is the coefficient of friction (COF) between the rope and capstan materials, $\varphi$ is the total angle swept by all turns of the rope, measured in radians (i.e., with one full turn the angle), as shown in Fig. (2).

Assumptions:

1. The rope is on the verge of full sliding, i.e. $T_{\text {laod }}$ is the maximum load that one can hold ensuring the effective angle of lap.

2. The rope line should not be rigid, otherwise may result in significant force lost during bending.

3. The rope should be made of pliable material.

From the Eq.1, it is seen that the gain in force propagates exponentially with the COF, the number of turns and the contact angle. Note that the cylinder radius has no influence on the gain in force. The Table 1 shows the factor $e^{\mu p}$ based on the number of turns and COF. 


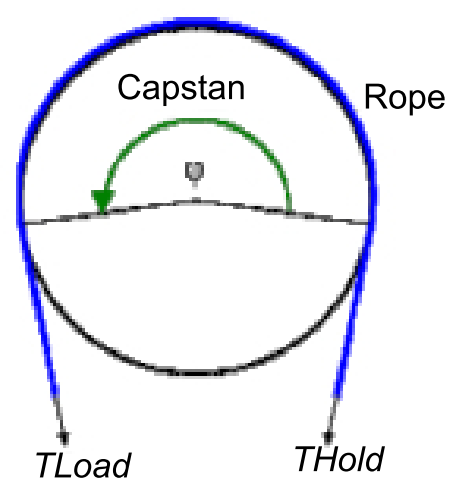

Fig. (2). Working principle of mechanical power amplifier.

Table 1. Theoretical Study of Capstan Principle.

\begin{tabular}{|c|c|c|c|c|c|c|c|}
\hline \multirow{2}{*}{$\begin{array}{c}\text { Number } \\
\text { of Turns }\end{array}$} & \multicolumn{9}{|c|}{ Coefficient of Friction $(\boldsymbol{\mu})$} \\
\cline { 2 - 8 } & $\mathbf{0 . 1}$ & $\mathbf{0 . 2}$ & $\mathbf{0 . 3}$ & $\mathbf{0 . 4}$ & $\mathbf{0 . 5}$ & $\mathbf{0 . 6}$ & $\mathbf{0 . 7}$ \\
\hline 1 & 1.9 & 3.5 & 6.6 & 12 & 23 & 1831 & 81 \\
\hline 2 & 3.5 & 12 & 43 & 152 & 535 & 81612 & 437503 \\
\hline 3 & 6.6 & 43 & 286 & 1881 & 12392 & 3540026 & 43702631 \\
\hline 4 & 12 & 152 & 1881 & 23228 & 286751 & & \\
\hline
\end{tabular}

From Table 1, it is seen that why one seldom sees a sheet (a rope to the loose side of a sail) wound more than three turns around a winch. The force gain would be extreme besides being counter-productive since there is risk of a riding turn, result being that the sheet will foul, form a knot and not run out when eased (by slacking grip on the tail (free end), or in land talk, one lets go of the hold end. It is both ancient and modern practice for anchor capstans and jib winches to be slightly flared out at the base, rather than cylindrical, to prevent the rope (anchor warp or sail sheet) from sliding down. The rope wound several times around the winch can slip upwards gradually, with little risk of a riding turn, provided it is tailed (loose end is pulled clear), by hand or a self-trailer. Using this principle, it is thus possible to develop a mechanical power amplifier, that will amplify the small control force applied by means of an input motor. The output of the device can then be used for the demonstration of load positioning application.

\section{PROBLEM FORMULATION AND OBJECTIVE}

After studying research papers, patents \& Technical reports as mentioned in reference section, we have decided the basis of this research work that the mechanical power amplifier generally consists of rope wound around the drum shall have compact design with elastic rope which should not be rigid so that it can amplify the load connected to output end of rope by virtue of its interaction with the tension in the rope, coefficient of friction between rope \& drum material, number of turn of rope. While some of the parameters like drum diameter, input driving system consists of motor drive which should be optimized to control cost and make the compact design. It also eliminates the need of any other device such as a transducer, pneumatic valve to change energy form required for controlled position and motion of heavy loads. The aim of this work is to design and test the proposed prototype of the power amplifier to evaluate its performance used in the aforesaid application through design optimization for a number of turns of rope, material and proper sizing of its assembly.

In order to execute the above-stated aim, following objectives were set in this work:

- Development of a mathematical model for capstan drum.

- Design and development of power amplifier mechanism for kinematic linkage arrangement for input and output arms, location and specifications of the gear train.

- Manufacturing and assembly of the power amplifier.

- To perform test $\&$ trial on mechanical power amplifier with different rope materials to determine performance characteristics. 


\section{EXPERIMENTAL SET-UP AND CONSTRUCTION}

A capstan is a simple mechanical amplifier-rope wound on a motor-driven drum. The drums rotate continuously but communicate torque only when the input shaft is rotated to constricts drum A as shown in Fig. (3).

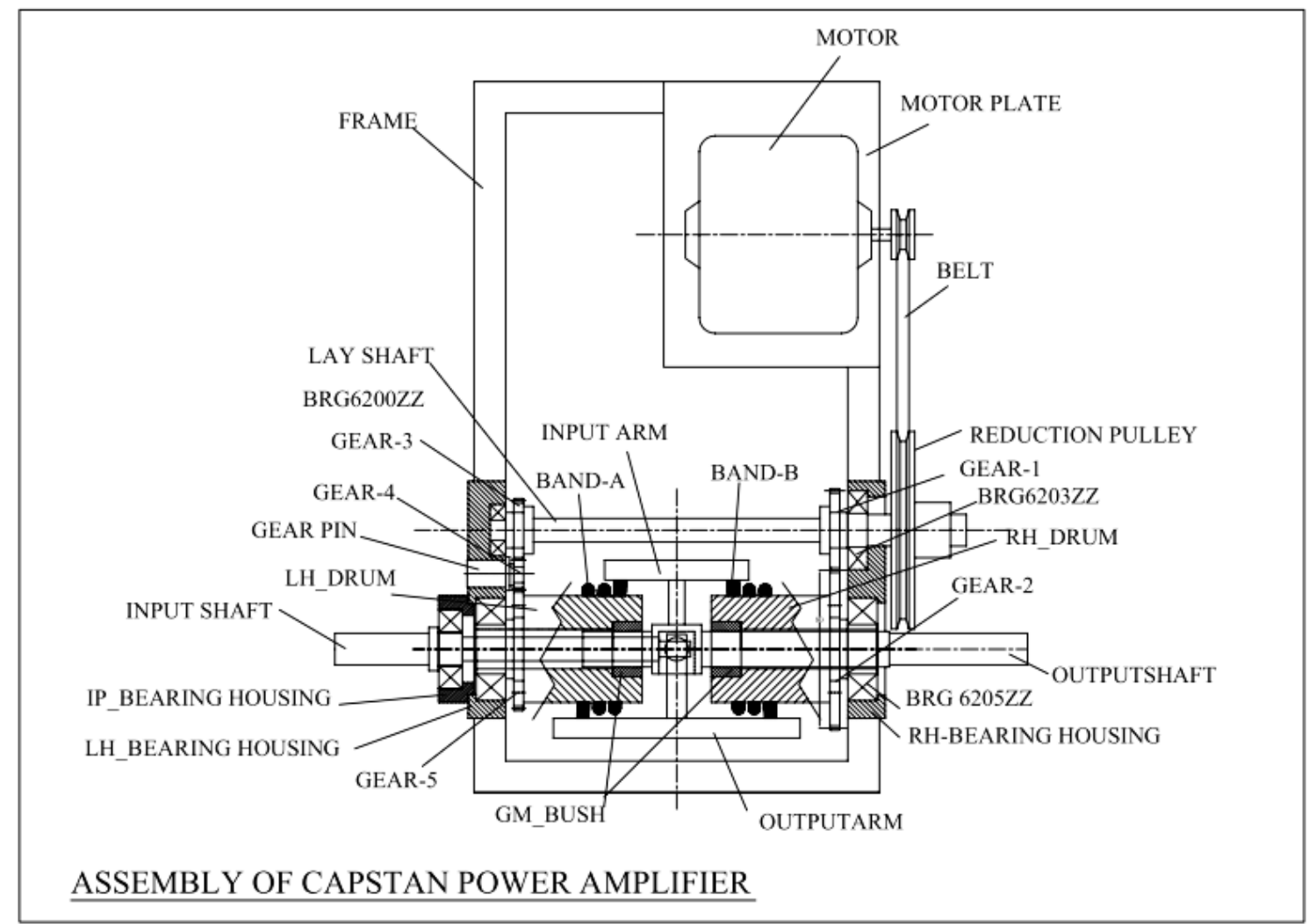

Fig. (3). Experimental set-up for capstan power amplifier.

Overrun of output is stopped by the drum, when it constricts the band B on this drum. Slip takes place until the slack is taken up on the free end. The force required at the free end to lift the load depends on the COF and the number of turns. The power amplifier delivers an output in both directions with an exact angular positioning of connecting bands $\mathrm{A}$ and $\mathrm{B}$.

When the input shaft is turned clockwise $(\mathrm{CW})$, the input arm takes up the slack on band A, locking it to its drum. As the load end of locked band $\mathrm{A}$ is linked to the output arm, it transmits the $\mathrm{CW}$ motion of the driven drum on which it is wound to the output shaft. The belt friction equation or capstan equation relates the hold-force to the load-force if a flexible line is wound around a cylinder (a bollard, a winch). A capstan-type device operates is on a principle as "a small holding force exerted on one side can carry a much larger loading force on the other side". By connecting bands $\mathrm{A}$ and B to an input shaft and arm, the power amplifier provides an output in both directions, plus accurate angular positioning. When the input shaft is turned $\mathrm{CW}$, the input arm takes up the slack on band A, locking it to its drum. In as much as the load end of locked band A is connected to the output arm, it transmits the clockwise motion of the tail drum on which it is wound, to the output shaft. Hence the band B slacks off and slips on its drum. When the clockwise motion of the input shaft stops, tension on band $\mathrm{A}$ is unconfined and it slips on its own drum. If the output shaft attempts to overrun, the output arm will apply tension to band B, causing it to tighten on the counter clockwise rotating drum and stop the shaft. Motor delivers power to the input shaft in clockwise direction whereas drives drum-B in an anticlockwise direction. The torque amplification depends upon the coefficient of friction between drum and band, the diameter of the drums and the number of wraps on the bands on their respective drums. Input power delivered to the input shaft is multiplied using the above amplifier arrangement and delivered to the output shaft.

The prototype of Capstan mechanical power amplifier as shown in Fig. (4) consists of the following components: 


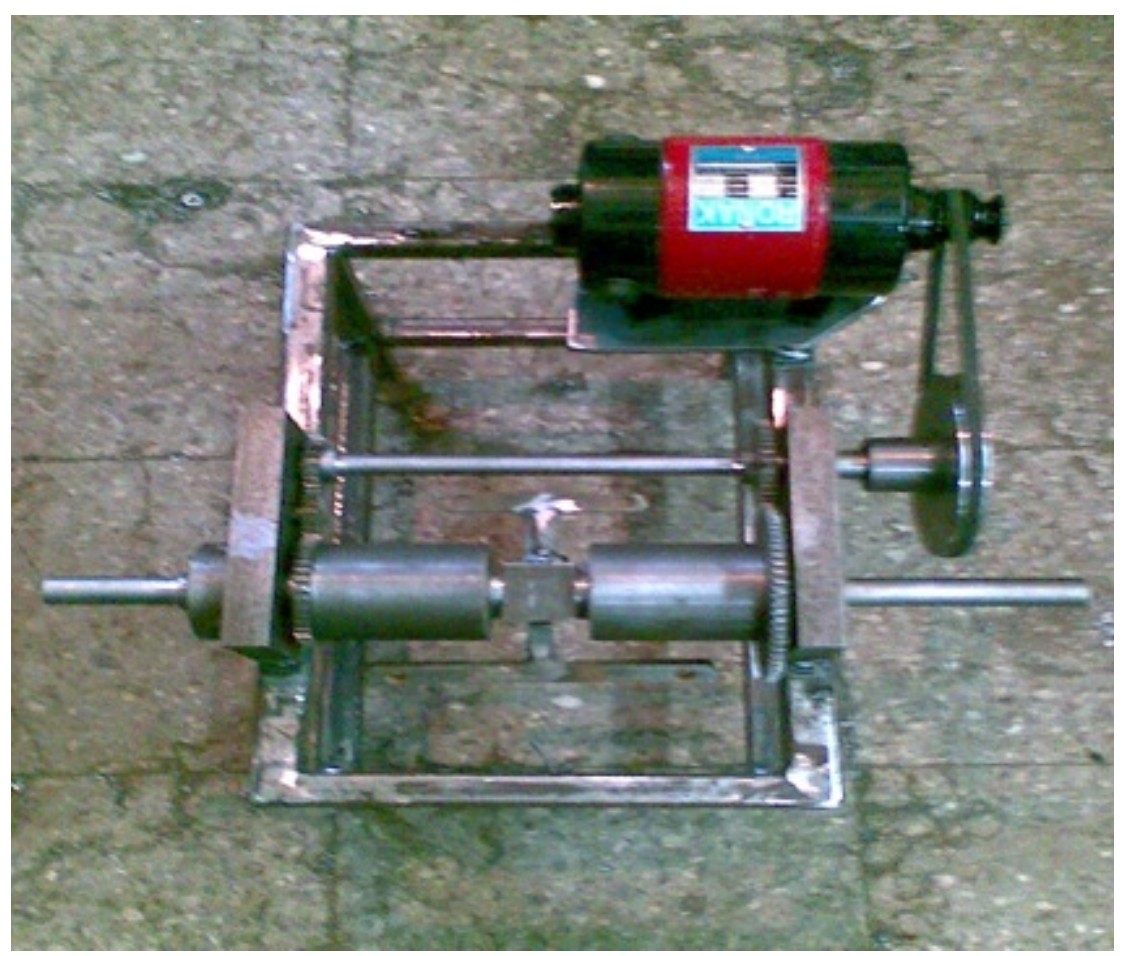

Fig. (4). Fabricated assembly of mechanical power amplifier.

\subsection{Electrical Motor}

The electrical motor is a single phase AC motor of 50-watt capacity and 0 to $9500 \mathrm{rpm}$ variable speed. The speed control is done by means of an electronic speed variator. The motor carries the motor pulley which connected to the reduction pulley mounted on the layshaft which forms the drive for the system.

\subsubsection{Motor Selection}

The power is transmitted to the input shaft of the amplifier by means of an open belt drive using two pulleys and belt, the specifications of the drive are as follows,
i. Motor pulley diameter $=25 \mathrm{~mm}$
ii. Input shaft pulley diameter $=100 \mathrm{~mm}$
iii. Reduction ratio $(i)=4$
iv. Input speed $=2100 \mathrm{rpm}$
v. Reduction ratio $=4$
vi. Output speed at lay shaft $=2100 / 4=525 \mathrm{rpm}$

Power $=2 \times \pi \times 2100 \times .20 / 60=43.98 \mathrm{~W}$.

Hence motor of 50 watt is selected with following details.

a. Motor type: single phase AC Motor .

b. Torque: $2 \mathrm{kgcm}$.

c. Speed: $6000 \mathrm{rpm}$.

d. Input power: 50 watt.

\subsection{Lay Shaft}

The layshaft made of material EN4 with mechanical properties as per Table 2 is held between two ball bearings mounted in bearing housing. The layshaft carries a set of gears from the gear train and the reduction pulley at one end. 
Table 2. Mechanical properties of EN24 material.

\begin{tabular}{|c|c|c|}
\hline Designation & Ultimate Tensile Strength N/mm & Yield Strength N/mm $^{2}$ \\
\hline EN 24 (40 N; 2 $\mathrm{c}_{\mathrm{r}} 1$ Mo 28) & 720 & 600 \\
\hline
\end{tabular}

\subsection{Gear Train Specification}

The gear train comprises of five gears namely:

Gear-1: 1.5 module, 18 teeth, face width $5 \mathrm{~mm}$

Gear-2: 1.5 module, 20 teeth, face width $5 \mathrm{~mm}$

Gear-3: 1.5 module, 40 teeth, face width $5 \mathrm{~mm}$

Gear-4: 1.5 module, 32 teeth, face width $5 \mathrm{~mm}$

Gear-5: 1.5 module, 64 teeth, face width $5 \mathrm{~mm}$

\subsection{LH and RH Drums}

The left and right hand drums are mounted in bearings $6005 \mathrm{ZZ}$ respectively in the bearing housing and carry gun metal bushing that supports the output shaft. The band is wound on the drums and it is further connected to the input and out arms respectively at its two ends.

\subsection{Input and Output Arms}

The input and out arms are connected to the input shaft and output shaft respectively. The bands wound on the drums are connected to these arms at their two ends.

\subsection{Input Shaft}

The input shaft is mounted in a ball bearing $6203 \mathrm{zz}$ held in the input shaft housing at one end whereas the other end is connected to the input arm.

\subsection{Output Shaft}

The output shaft held in gunmetal bush bearings mounted inside the load drums and it is made hollow at one end so that the input shaft passes through it.

\subsection{Frame}

The frame is the structural member that supports the entire power amplifier assembly, the LH \& RH bearing housings, motor plate are welded to the frame.

\subsection{Rope}

The rope is a cotton beaded rope of $6 \mathrm{~mm}$ diameter with the left hand band wound on the left hand drum and the right hand band wound on the right hand drum. The ends of these bands are fixed to the input and output arms respectively. Table 3 shows the list of various components with the material specification.

\section{Table 3. List of component.}

\begin{tabular}{|c|c|c|c|c|}
\hline Sr. No. & Part Code & Description & Qty & Material \\
\hline 1. & pamp-1 & Motor & 01 & std \\
\hline 2. & pamp -2 & Belt & 01 & std \\
\hline 3. & pamp -3 & reduction pulley & 01 & en9 \\
\hline 4. & pamp -4 & rh_brg_housing & 01 & en9 \\
\hline 5. & pamp -5 & Frame & 01 & $\mathrm{~ms}$ \\
\hline 6. & pamp -6 & motor plate & 01 & $\mathrm{~ms}$ \\
\hline 7. & pamp -7 & lay shaft & 01 & en24 \\
\hline 8. & pamp -8 & ip_shaft & 01 & en24 \\
\hline
\end{tabular}


(Table 3) contd.....

\begin{tabular}{|c|c|c|c|c|}
\hline Sr. No. & Part Code & Description & Qty & Material \\
\hline 9. & pamp -9 & op_shaft & 01 & en24 \\
\hline 10. & pamp -10 & lh_drum & 01 & en24 \\
\hline 11. & pamp -11 & rh_drum & 01 & en24 \\
\hline 12. & pamp -12 & input arm & 01 & en9 \\
\hline 13. & pamp -13 & output arm & 01 & en9 \\
\hline 14. & pamp -14 & Gears & 05 & std \\
\hline 15. & pamp -15 & Band & 01 & std \\
\hline 16. & pamp -16 & ip_brg housing & 01 & en9 \\
\hline 17. & pamp-17 & gear pin & 01 & en24 \\
\hline 18. & pamp -18 & brg $6205 \mathrm{zz}$ & 02 & std \\
\hline 19. & pamp-19 & brg $6203 \mathrm{zz}$ & 02 & std \\
\hline 20. & pamp-20 & brg $6200 \mathrm{zz}$ & 01 & std \\
\hline
\end{tabular}

\section{TEST TRIALS AND MEASUREMENT}

In order to conduct trial, a dyno-brake pulley cord, weight pan is provided on the output shaft.

\subsection{Input Data}

A) Drive Motor

AC230 Volt

0.5 Amp, 50 watt

$50 \mathrm{~Hz}, 200$ to $9500 \mathrm{rpm}$

TEFC COMMUTATOR MOTOR

B) Select the leather material for rope and wound three numbers of the turn of it around corresponding drums. Then, trials are conducted by the following procedure;

\subsection{Procedure}

1. Start motor by turning electronic speed variator knob.

2. Let mechanism run \& stabilize at a certain speed (say $1300 \mathrm{rpm}$ )

3. Place the weight in the weight pan attached to input arm bracket of LH side input shaft and add 100 gm weight into weight pan. Simultaneously note down the speed for this load by means of the tachometer.

4. Keep adding another $100 \mathrm{gm}$ weight into the weight pan \& take a reading.

5. Note down the reading on an electronic loading cell which is attached to output arm bracket mounted on load pulley fixed on RH side output shaft.

6. Calculate the input torque and output torque by using arm length $=100 \mathrm{~mm}$.

7. Tabulate the readings in the observation table.

8. Plot Torque versus speed characteristic, power versus speed characteristic.

9. Repeat above steps of trial by varying rope material as woolen, cotton and steel.

10. Sample Calculations

Here sample calculations for observation 1 as Table $\mathbf{6}$ are given as;

- Input Torque $=$ Load in the weight pan $(\mathrm{N}) \times$ Length of input arm $(\mathrm{m})=0.1 \times 9.81 \times 0.10=0.0981 \mathrm{~N}-\mathrm{m}$

- Output Torque $=$ Electronic load cell reading $(\mathrm{N}) \times$ Length of output arm $(\mathrm{m})=0.170 \times 9.81 \times 0.1=0.1667 \mathrm{~N}-\mathrm{m}$

- Power consumed across output shaft $=2 \times \pi \times \mathrm{N} \times \mathrm{T} / 60=2 \times 3.143 \times 2100 \times 0.1667 / 60=36.656 \mathrm{Watt}$

- Efficiency $=$ Input $/$ output $=36.656 / 71.56=51.23 \%$

From the observation of Table $\mathbf{6}$ and its calculations, it is evident that maximum amplification factor for leather rope 
material is 2.23. In a similar way, from observation Table $\mathbf{5}$ and its calculations, maximum amplification factor for steel rope material is 1.32 and from observation Table 7 , that of woven cotton is 1.867 .

\section{RESULT AND DISCUSSION}

To validate the experimental findings, a number of trials were conducted by varying input loads in weight pan from $100 \mathrm{gm}$ to $1 \mathrm{~kg}$ and corresponding readings of electronic load cell, variation in the speed, input torque, output torque, power and efficiency are noted. Results obtained by using rope material as leather and by using two numbers of turns are tabulated in Table 6. Similarly, Tables $\mathbf{5}$ and $\mathbf{7}$ show the observations for steel and woven cotton. From Tables $\mathbf{4}$ and $\mathbf{6}$, relationship between speed, torque, power, efficiency of power amplifier assembly is plotted as shown in Figs. (5, 6 and 7). The results are remarkably consistent with experimental measurements including favorable calculation of amplification factor.

Table 4. Loading and unloading data.

\begin{tabular}{|c|c|c|c|c|c|}
\hline \multirow{2}{*}{$\begin{array}{c}\text { Sr. } \\
\text { No. }\end{array}$} & Weight (gm) & Speed rpm & $\begin{array}{c}\text { Weight } \\
(\mathbf{g m})\end{array}$ & Speed (rpm) & $\begin{array}{c}\text { Mean Speed } \\
(\mathbf{r p m})\end{array}$ \\
\cline { 2 - 6 } & & 2100 & 100 & 2100 & 2100 \\
\hline 1. & 100 & 1960 & 150 & 1960 & 1960 \\
\hline 2. & 150 & 1750 & 200 & 1750 & 1750 \\
\hline 3. & 200 & 1600 & 250 & 1600 & 1600 \\
\hline 4. & 250 & 1250 & 300 & 1250 & 1250 \\
\hline 5. & 300 & 1050 & 350 & 1050 & 1050 \\
\hline 6. & 350 & 810 & 500 & 810 & 810 \\
\hline 7. & 500 & 650 & 600 & 650 & 650 \\
\hline 8. & 600 & 535 & 700 & 535 & 535 \\
\hline 9. & 700 & 520 & 800 & 520 & 520 \\
\hline 10. & 800 & &
\end{tabular}

Table 5. Observation for power amplification factor with steel rope.

\begin{tabular}{|c|c|c|c|c|c|c|c|c|}
\hline \multirow{2}{*}{$\begin{array}{l}\text { Sr. } \\
\text { No. }\end{array}$} & \multirow{2}{*}{$\begin{array}{c}\begin{array}{c}\text { Load at } \\
\text { Input } \\
\text { Shaft }\end{array} \\
\text { (gm) }\end{array}$} & \multirow{2}{*}{$\begin{array}{l}\text { Load Cell } \\
\text { Reading at } \\
\text { Output Shaft } \\
\quad \text { (gm) }\end{array}$} & \multirow{2}{*}{\begin{tabular}{|l|} 
Speed \\
$(\mathrm{rpm})$ \\
\end{tabular}} & \multirow{2}{*}{$\begin{array}{c}\text { Input Torque } \\
(\mathrm{N}-\mathrm{m})\end{array}$} & \multirow{2}{*}{$\begin{array}{c}\begin{array}{c}\text { Output Arm } \\
\text { Amplified Torque }\end{array} \\
(\mathrm{N}-\mathrm{m})\end{array}$} & \multirow{2}{*}{$\begin{array}{c}\begin{array}{c}\text { Power Consumed } \\
\text { Across Output Shaft }\end{array} \\
\text { (watt) }\end{array}$} & \multirow{2}{*}{$\begin{array}{c}\text { Power Amplification } \\
\text { Factor }=\text { (Output } \\
\text { Torque } / \text { Input } \\
\text { Torque) } \\
\end{array}$} & \multirow{2}{*}{\begin{tabular}{|c|} 
Efficiency \\
$(\%)$
\end{tabular}} \\
\hline & & & & & & & & \\
\hline 1 & 100 & 110 & 2100 & 0.0981 & 0.10791 & 23.718618 & 1.1 & 33.1439 \\
\hline 2 & 150 & 180 & 1960 & 0.14715 & 0.17658 & 36.2247984 & 1.2 & 45.17521 \\
\hline 3 & 200 & 233.3334 & 1750 & 0.1962 & 0.228900065 & 41.92686198 & 1.166667 & 48.7877 \\
\hline 4 & 250 & 300 & 1600 & 0.24525 & 0.2943 & 49.28544 & 1.2 & 54.11748 \\
\hline 5 & 300 & 378 & 1250 & 0.2943 & 0.370818 & 48.515355 & 1.26 & 54.81697 \\
\hline 6 & 350 & 460.83345 & 1050 & 0.34335 & 0.452077614 & 49.68332983 & 1.316667 & 56.629 \\
\hline 7 & 500 & 614.2855 & 810 & 0.4905 & 0.602614076 & 51.08962132 & 1.228571 & 55.7840 \\
\hline 8 & 600 & 697.5 & 650 & 0.5886 & 0.6842475 & 46.55163825 & 1.1625 & 51.6985 \\
\hline 9 & 700 & 882 & 535 & 0.6867 & 0.865242 & 48.45066786 & 1.26 & 54.7756 \\
\hline 10 & 800 & 1024 & 520 & 0.7848 & 1.004544 & 54.67398144 & 1.28 & 58.9705 \\
\hline 11 & 1000 & 1290 & 380 & 0.981 & 1.26549 & 50.3327556 & 1.29 & 56.54245 \\
\hline
\end{tabular}

Table 6. Observation for power amplification factor with leather rope.

\begin{tabular}{|c|c|c|c|c|c|c|c|c|}
\hline \multirow[t]{2}{*}{$\begin{array}{l}\text { Sr. } \\
\text { No. }\end{array}$} & $\begin{array}{l}\text { Load at } \\
\text { Input } \\
\text { Shaft }\end{array}$ & \multirow{2}{*}{$\begin{array}{c}\text { Load Cell } \\
\text { Reading at } \\
\text { Output Shaft } \\
\text { (gm) }\end{array}$} & \multirow{2}{*}{\begin{tabular}{|l|} 
Speed \\
$($ rpm $)$ \\
\end{tabular}} & \multirow{2}{*}{\begin{tabular}{|c|} 
Input Torque \\
(N-m) \\
\end{tabular}} & \multirow{2}{*}{$\begin{array}{c}\begin{array}{c}\text { Output Arm } \\
\text { Amplified Torque }\end{array} \\
(\mathrm{N}-\mathrm{m})\end{array}$} & \multirow{2}{*}{\begin{tabular}{|c|}
$\begin{array}{c}\text { Power Consumed Across } \\
\text { Output Shaft }\end{array}$ \\
(watt) \\
\end{tabular}} & \multirow{2}{*}{$\begin{array}{c}\text { Power Amplification } \\
\text { Factor }=\text { (Output } \\
\text { Torque } / \text { Input } \\
\text { Torque) }\end{array}$} & \multirow{2}{*}{$\begin{array}{c}\text { Efficiency } \\
(\%)\end{array}$} \\
\hline & (gm) & & & & & & & \\
\hline 1 & 100 & 170 & 2100 & 0.0981 & 0.16677 & 36.656046 & 1.7 & 51.22250825 \\
\hline 2 & 150 & 262.5 & 1960 & 0.14715 & 0.2575125 & 52.827831 & 1.75 & 65.88051963 \\
\hline 3 & 200 & 356 & 1750 & 0.1962 & 0.349236 & 63.968394 & 1.78 & 74.43612261 \\
\hline 4 & 250 & 450 & 1600 & 0.24525 & 0.44145 & 73.92816 & 1.8 & 81.17622256 \\
\hline
\end{tabular}




\begin{tabular}{|c|c|c|c|c|c|c|c|c|}
\hline \multirow[t]{2}{*}{$\begin{array}{l}\text { Sr. } \\
\text { No. }\end{array}$} & $\begin{array}{c}\text { Load at } \\
\text { Input } \\
\text { Shaft }\end{array}$ & $\begin{array}{c}\text { Load Cell } \\
\text { Reading at } \\
\text { Output Shaft }\end{array}$ & Speed & Input Torque & $\begin{array}{c}\text { Output Arm } \\
\text { Amplified Torque }\end{array}$ & $\begin{array}{c}\text { Power Consumed Across } \\
\text { Output Shaft }\end{array}$ & \multirow{2}{*}{$\begin{array}{c}\text { Power Amplification } \\
\text { Factor }=\text { (Output } \\
\text { Torque / Input } \\
\text { Torque) }\end{array}$} & Efficiency \\
\hline & (gm) & (gm) & $(\mathbf{r p m})$ & (N-m) & $(\mathrm{N}-\mathrm{m})$ & (watt) & & $(\%)$ \\
\hline 5 & 300 & 540 & 1250 & 0.2943 & 0.52974 & 69.30765 & 1.8 & 78.30996817 \\
\hline 6 & 350 & 647.5 & 1050 & 0.34335 & 0.6351975 & 69.80820525 & 1.85 & 79.56786874 \\
\hline 7 & 500 & 940 & 810 & 0.4905 & 0.92214 & 78.1790292 & 1.88 & 85.36264583 \\
\hline 8 & 600 & 1230 & 650 & 0.5886 & 1.20663 & 82.091061 & 2.05 & 91.16729388 \\
\hline 9 & 700 & 1477 & 535 & 0.6867 & 1.448937 & 81.13564221 & 2.11 & 91.72749805 \\
\hline 10 & 800 & 1624 & 520 & 0.7848 & 1.593144 & 86.70951744 & 2.03 & 93.52360221 \\
\hline 11 & 1000 & 2230 & 380 & 0.981 & 2.18763 & 87.0093372 & 2.23 & 97.74392716 \\
\hline
\end{tabular}

Table 7. Observation for power amplification factor with woven cotton rope.

\begin{tabular}{|c|c|c|c|c|c|c|c|c|}
\hline \multirow[t]{2}{*}{$\begin{array}{l}\text { Sr. } \\
\text { No. }\end{array}$} & $\begin{array}{c}\text { Load at } \\
\text { Input } \\
\text { Shaft }\end{array}$ & \multirow{2}{*}{$\begin{array}{l}\text { Load Cell } \\
\text { Reading at } \\
\text { Output Shaft } \\
\text { (gm) }\end{array}$} & Speed & Input Torque & $\begin{array}{c}\text { Output Arm } \\
\text { Amplified Torque }\end{array}$ & $\begin{array}{l}\text { Power Consumed } \\
\text { Across Output Shaft }\end{array}$ & \multirow{2}{*}{$\begin{array}{c}\text { Power Amplification } \\
\text { Factor }=\text { (Output } \\
\text { Torque / Input } \\
\text { Torque) }\end{array}$} & \multirow{2}{*}{$\begin{array}{c}\text { Efficiency } \\
(\%)\end{array}$} \\
\hline & (gm) & & $(\mathrm{rpm})$ & $(\mathrm{N}-\mathrm{m})$ & $(\mathrm{N}-\mathrm{m})$ & (watt) & & \\
\hline 1 & 100 & 150 & 2100 & 0.0981 & 0.14715 & 32.34357 & 1.1 & 45.19633081 \\
\hline 2 & 150 & 232.5 & 1960 & 0.14715 & 0.2280825 & 46.7903646 & 1.3 & 58.35131739 \\
\hline 3 & 200 & 314 & 1750 & 0.1962 & 0.308034 & 56.421561 & 1.433333 & 65.65433287 \\
\hline 4 & 250 & 400 & 1600 & 0.24525 & 0.3924 & 65.71392 & 1.5 & 72.15664228 \\
\hline 5 & 300 & 495 & 1250 & 0.2943 & 0.485595 & 63.5320125 & 1.6 & 71.78413748 \\
\hline 6 & 350 & 588 & 1050 & 0.34335 & 0.576828 & 63.3933972 & 1.75 & 72.25622675 \\
\hline 7 & 500 & 850 & 810 & 0.4905 & 0.83385 & 70.693803 & 1.857143 & 77.18962655 \\
\hline 8 & 600 & 1032 & 650 & 0.5886 & 1.012392 & 68.8764024 & 1.5625 & 76.49158315 \\
\hline 9 & 700 & 1239 & 535 & 0.6867 & 1.215459 & 68.06165247 & 1.48 & 76.94676376 \\
\hline 10 & 800 & 1472 & 520 & 0.7848 & 1.444032 & 78.59384832 & 1.39 & 84.7701616 \\
\hline 11 & 1000 & 1850 & 380 & 0.981 & 1.81485 & 72.182634 & 1.2 & 81.08801132 \\
\hline
\end{tabular}

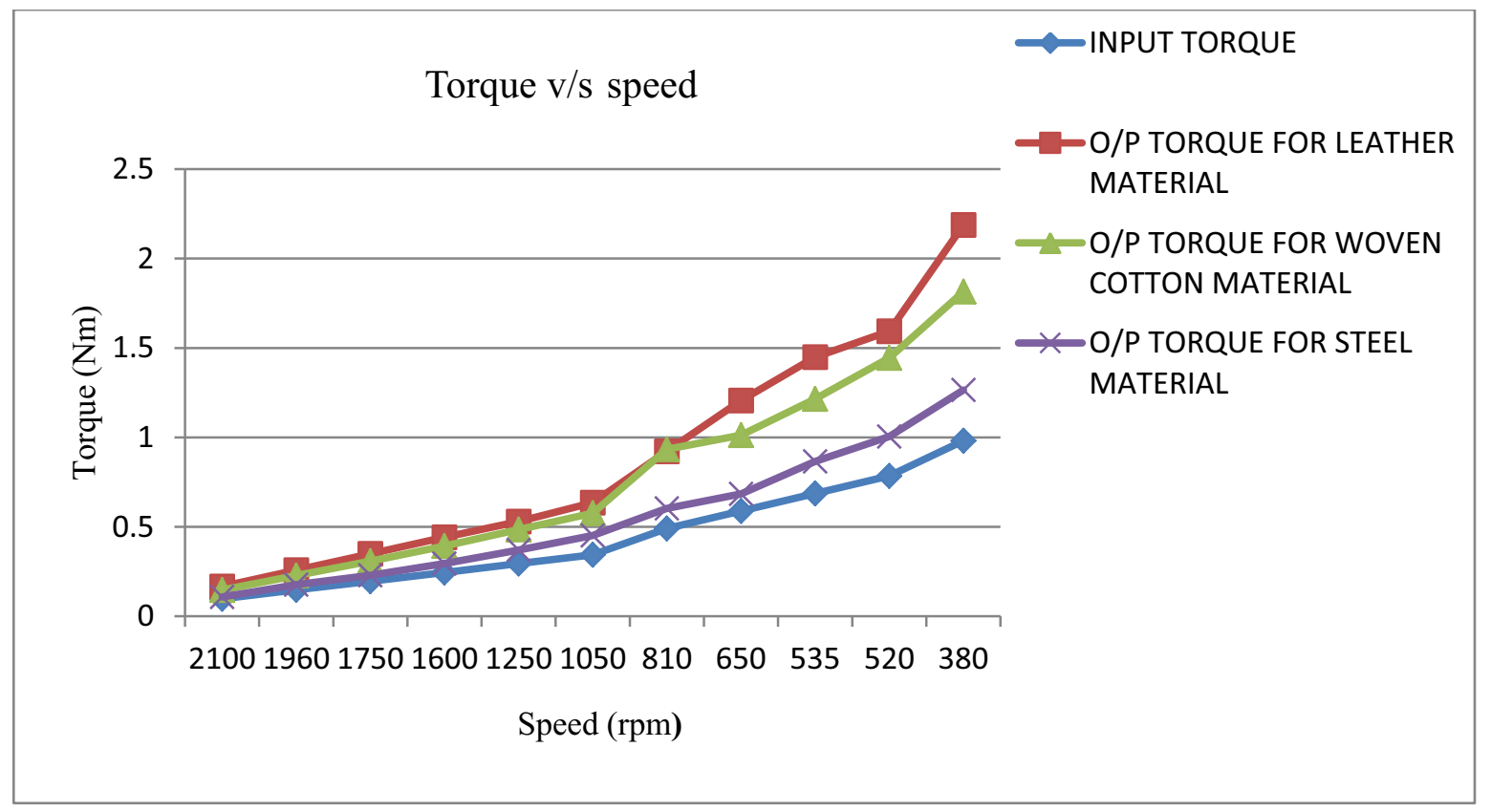

Fig. (5). Torque versus speed. 


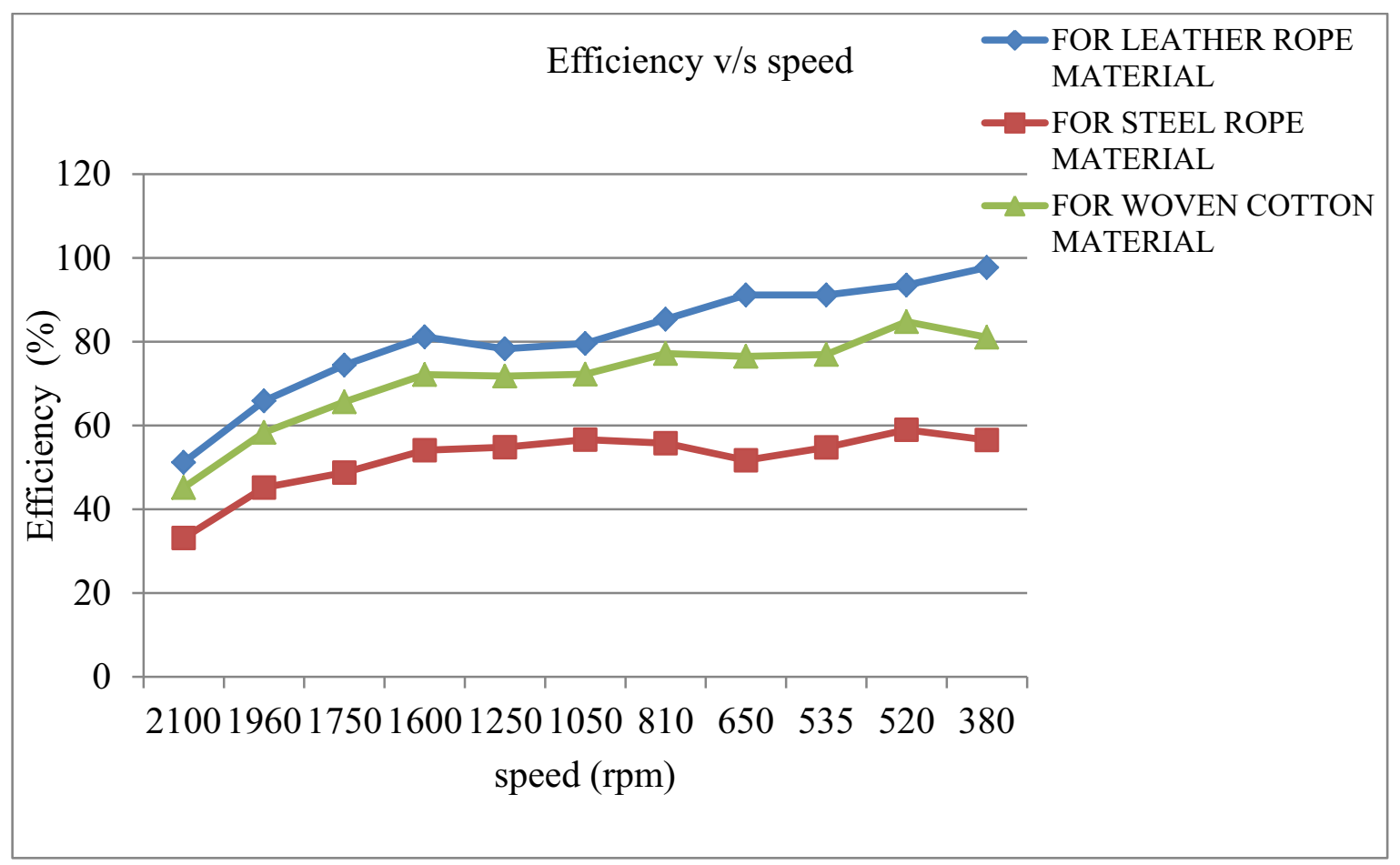

Fig. (6). Efficiency versus speed.

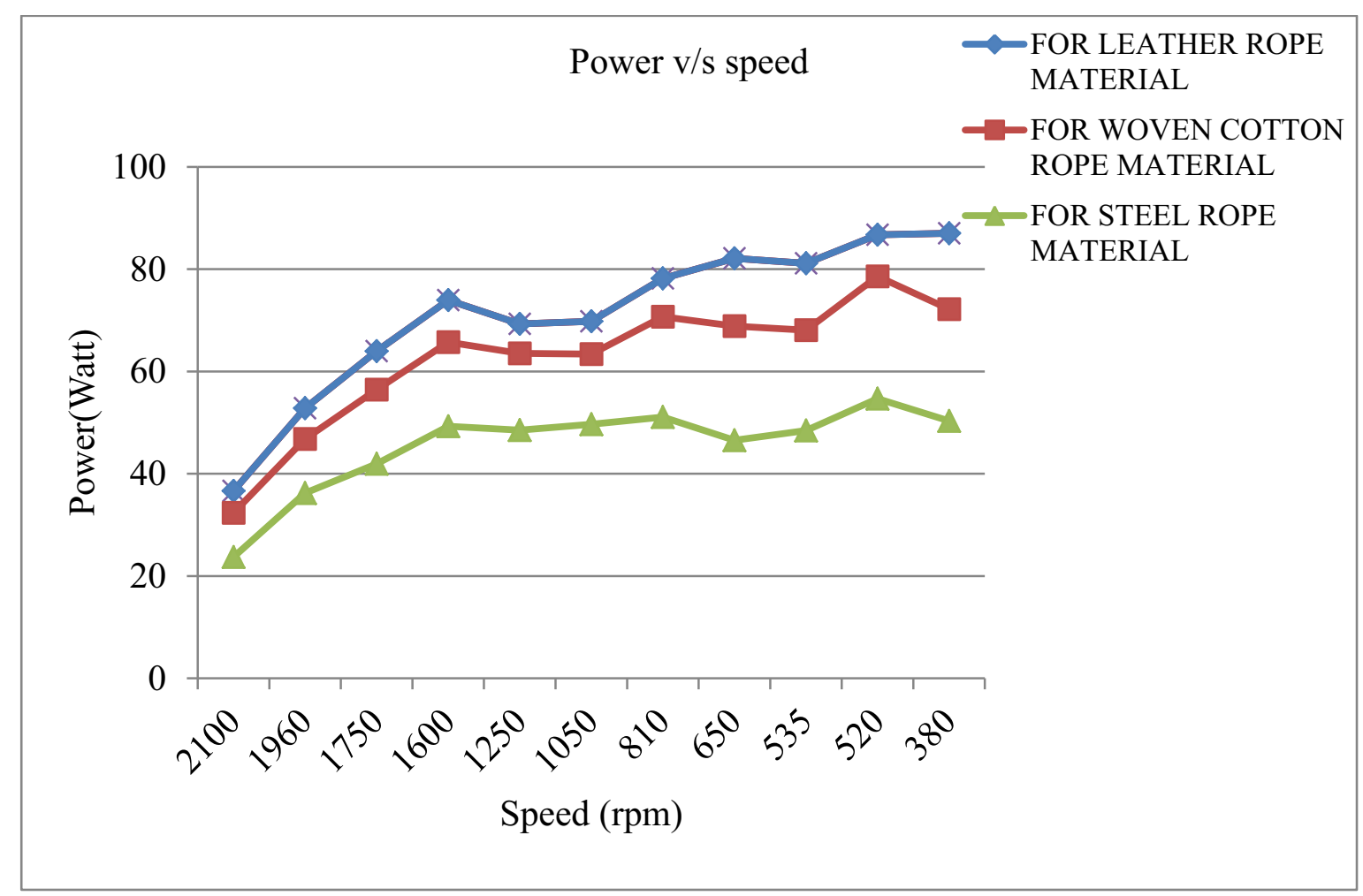

Fig. (7). Power versus speed.

From Fig. (5), it is observed that as speed goes on decreasing torque measured at the input shaft goes on increasing due to the increase in the applied input load. It is also observed that as speed goes on decreasing, torque measured at the output shaft goes on increasing. Torque varies in an inverse proportion to the speed, though the amplification factor goes on increasing as speed decreases. Maximum value of amplification factor is equal to 2.23 for leather rope material, 
1.867 for woven cotton material, 1.32 for steel material at low speed values with corresponding high torque value. Still variation in the values of amplification factor remains is very less. Maximum output torque obtained at speed $380 \mathrm{rpm}$ and is equal to $2.18 \mathrm{~N}-\mathrm{m}$ for leather material, 1.266 for steel rope material, 1.815 for woven rope material.

From Fig. (6), it is observed that as speed goes on decreasing, efficiency of the system goes on increasing. Hence initially speed is high, efficiency is less. As load on the system goes on increasing, efficiency of different power transmission system including belt drive and gear system goes on decreasing, hence overall efficiency of the system goes on decreasing after some threshold limit. The maximum efficiency of $97.74 \%$ is obtained for leather rope material at speed of $230 \mathrm{rpm}$ and input load of $1000 \mathrm{gm}$. Similarly, for woven cotton maximum efficiency is $84.87 \%$ is obtained at speed $520 \mathrm{rpm}$ and $800 \mathrm{gm}$. For steel rope material, it is 58.97 at speed $520 \mathrm{rpm}$ and $800 \mathrm{gm}$.

From Fig. (7), it is observed that as speed goes on decreasing, power across output shaft of the system goes on increasing. Hence initially speed is high, power is less. As load across output shaft goes on increasing, speed goes on decreasing hence power across output shaft goes on increasing. Maximum power obtained at output arm for leather rope is 87.008 watts, whereas for woven cotton rope is 78.59 watts and for steel is 54.67 watts.

From experimental investigations, it is seen that the performance of mechanical power amplifier can be enhanced by increasing its amplification factor. Amplification factor depends upon the following variables:

1. It depends upon angle of wrap of rope wound around capstan drum i.e. no. of turns of rope. Amplification factor is exponentially proportional to the number of turns. But if we increase no. of turns beyond two or three, it will have binding of rope around drum which indeed decreases kinetic energy intake of rotating drum taken from electric motor drive. It results in the loss of power and efficiency of transmission which gives absurd results. Taking this into account, selecting optimum number of turns i.e. two or three number of turns will give desired results.

2. It also depends upon the coefficient of friction between rope material and drum. By selecting proper elastic rope material having high coefficient of friction, power amplification factor can be enhanced.

3. It is evident that leather to steel rope-drum pair has the highest coefficient of friction (0.6) among the remaining materials i.e. woven cotton, steel.

\section{CONCLUSION}

The main objective of this work was to compute the amplification factor of mechanical power amplifier for different rope materials like leather, woven cotton and steel rope. This objective is achieved with the exhaustive analytical and experimental analysis. From the experimental analysis, it confirms the fact that by keeping an optimum number of turns equal to two, power amplification factor is found to be 2.23 for leather contact, 1.867 for woven cotton contact, 1.32 for steel contact of rope. It shows that power amplification is higher for leather as compared to woven cotton and steel. The results were remarkably consistent with experimental measurements including favorable calculation of amplification factor.

\section{CONSENT FOR PUBLICATION}

Not applicable.

\section{CONFLICT OF INTERESTS}

The authors declare no conflict of interest, financial or otherwise.

\section{ACKNOWLEDGEMENTS}

Authors would to thank Mr. Sagar Wasunde, President of Design Logic Pvt. Ltd., Pimpiri, Pune for helping us in formulating the problem, providing the necessary input for manufacturing and guiding to achieve the objective.

\section{REFERENCES}

[1] S.W. Attaway, "The mechanics of friction in rope rescue", In: Proceedings of the International Technical Rescue Symposium, ITRS 99, Fort Collins: Colorado, USA, 1999, pp. 1-16.

[2] G.C. Thomas, C.C. Gimenez, E.D. Chin, P.A. Carmedelle, and A.M. Hoover, "Controllable High Force amplification using Elastic Cable Capstan", In: Proceedings of ASME 2012 international design engineering technical Conference, IDETC/CIE 2012, Chicago, IL, USA, 2012, pp. 885-889. 
[http://dx.doi.org/10.1115/DETC2012-71295]

[3] T. Morten, S. Snekkerveien, J. Helvik, and I. Hernik, "Petroleum Well Intervention Winch System", World Intellectual Property Organization WO, vol. 2013/036145, p. A2, 2013.

[4] C.J. Brandt, "Capstan operated Automated Trackside Railed Car Discharge Gate system", U. S. Patent US 2011/0219981 A1, September 15, 2011.

[5] B. Schena, and T. Cooper, "Compact Capstan Design For Robotic Surgical System", U. S. Patent US 2008/0009838 A1, January 10, 2008.

[6] M. Tjader, "Dual Capstan Puller and Method", U. S. Patent US 2011/0233494 A1, Sep. $29,2011$.

[7] H. E. Jenkins, "Capstan speed Control in the Optical Fiber drawing Process- A Case Study for Mechatronics", In: Proceedings of ASEE Southeast Section Conference, Louisville, USA, 2007, pp. 1-11.

[8] B. Bingaman, "Capstan Drive System For High Speed Tape Duplicator", U. S. Patent US 3 431 950, February $14,1984$.

[9] R. Lewis, and S. Oaks, "Dual Capstan Drive System", U. S. Patent US 3583 618, June 8, 1971.

[10] V.R. Gambhire, and M.V. Mane, "Design and development of mechanical power amplifier", International Journal of Research in Engineering and Technology, vol. 3, no. 8, pp. 181-184, 2014. [http://dx.doi.org/10.15623/ijret.2014.0308028]

[11] X.Y. Hu, J.H. Jia, and S.T. Tu, "Displacement amplifier design for an extensometer in high temperature deformation monitoring", Procedia Eng., vol. 29, pp. 1872-1876, 2012.

[http://dx.doi.org/10.1016/j.proeng.2012.01.229]

[12] Y. Hu, Y. Yan, L. Wang, and X. Qian, "Non-contact vibration monitoring of power transmission belts through electrostatic sensing", IEEE Sensors, vol. 16, no. 10, pp. 3541-3550, 2016. [http://dx.doi.org/10.1109/JSEN.2016.2530159]

[13] I. Shahosseini, and K. Najafi, "Mechanical amplifier for translational kinetic energy harvesters", J. Phys. Conf. Ser., vol. 557, pp. 1-6, 2014. [http://dx.doi.org/10.1088/1742-6596/557/1/012135]

[14] T. Mushiri, and C. Mbohwa, "Design of a Power Saving Industrial Conveyor System", In: Proceedings of the World Congress on Engineering and Computer Science (WCECS -2016), vol. II. University of Johannesburg: San Francisco, USA, 2016, pp. 1-6.

[15] J. Pawar, D.D. Date, and P. Satav, "Design and optimization of roller in belt conveyor system for weight reduction", International Journal of Mechanical and Production Engineering, vol. 2, no. 8, pp. 34-37, 2014.

\section{(C) 2018 S. H. Gawande.}

This is an open access article distributed under the terms of the Creative Commons Attribution 4.0 International Public License (CC-BY 4.0), a copy of which is available at: (https:/creativecommons.org/licenses/by/4.0/legalcode). This license permits unrestricted use, distribution, and reproduction in any medium, provided the original author and source are credited. 